\title{
VARIATION IN AND ECOLOGY OF ASPEN
}

\author{
Dr. Alan A. Beetle \\ Division of Plant Science \\ University of Wyoming \\ Laramie, Wyoming
}

\section{Objectives}

Aspen is a key range plant on elk winter range. The suppression of normal stands characterizes Jackson Hole. This long term study focuses on both the autecology and the synecology of Populus tremuloides.

\section{Procedures}

15 years ago a survey was made of aspen stands along Pacific Creek from the Snake River to the wilderness boundary. These stands have been mapped and measured every year since.

Annual inspection of aspen burns have used the same techniques. Annual inspection of range exclosures have resulted in measurement of aspen growth, changes in aspen understory, shrub height, and density, frequency and ground cover of herbaceous plants. These data are used to determine the condition classes of game ranges.

\section{$\underline{\text { Results }}$}

All exclosures in the Jackson Hole area show fenceline contrasts. All aspen stands show structural alteration. There is no evidence of increased aspen regeneration resulting from fire.

A special study has shown that aspen is not seral in many cases, that fir is a natural component of climax aspen, that lodgepole pine invasion indicates a disclimax.

Another special study has shown that the distribution patterns of members of the Scabrellae/Secundae complex of Poa are descrete.

\section{Conclusions}

Yearly measurements of root sprouts in quaking aspen stands in Jackson Hole since 1964 show that, each year, available annual growth (sometimes more) is consumed completely during the seasons following the yearly increment. As a result, a conspicuous gap between the snowline and the highline is characteristic of all stands except those on north slopes which are protected by the depth of the winter snow pack. Elk are the primary consumers. Second, but significant, are the moose. 


\section{Acknowledgments:}

The use of facilities (herbarium and library) at Grand Teton National Park Headquarters at Moose, and the use of the Jackson Hole Biological Research Station are acknowledged.

Eldon Ayres, a graduate student in range management, University of Wyoming, assumed primary responsibility for a study of the distribution of species of Poa.

Jeffrey Weinstein, a senior in range management, University of Wyoming, assumed primary responsibility for a study of shrub heights and densities inside and outside of Jackson Hole exclosures.

Literature Cited:

Beetle, A. A. 1961. Range survey in Teton County, Wyoming. Part I. Ecology of range resources. Wyo. Agric. Exp. Sta. Bul. 376:1-42.

Beetle, A. A. 1962. Range survey in Teton County, Wyoming. Part II. Utilization and condition classes. Wyo. Agr. Exp. Sta. Bul1. 400:1-38.

Beetle, A. A. 1968. Range survey in Teton County, Wyoming. Part III. Trends in vegetation. Wyo. Agr. Exp. Sta. Res. Jour. 26:1-15.

Beetle, A. A. 1974. Range survey in Teton County, Wyoming. Part IV. Quaking aspen. Wyo. Agr. Exp. Sta. Sci. Monograph $27: 1-28$.

Beetle, A. A. 1974. The zootic disclimax concept. Jour. Range Management $27: 30-32$. 